\title{
Recommended Further Readings
}

\section{Bioethics}

Beauchamp, Tom, and James Childress, Principles of Biomedical Ethics, 8th ed. (New York: Oxford University Press, 2019).

O'Neill, Onora, Autonomy and Trust in Bioethics (Cambridge: Cambridge University Press, 2002).

Steinbock, Bonnie (ed.), The Oxford Handbook of Bioethics (New York: Oxford University Press, 2007).

Sugarman, Jeremy, and Daniel Sulmasy (eds.), Methods in Medical Ethics, 2nd ed. (Washington, DC: Georgetown University Press, 2010).

Veatch, Robert, $A$ Theory of Medical Ethics (New York: Basic Books, I98 I).

\section{Moral Philosophy}

Griffin, James, Well-Being (Oxford: Clarendon, I986).

Hooker, Brad, Ideal Code, Real World (Oxford: Clarendon, 20oo).

Kamm, Frances, Intricate Ethics: Rights, Responsibilities, and Permissible Harm (New York: Oxford University Press, 2007).

Parfit, Derek, Reasons and Persons (Oxford: Clarendon, I984).

Singer, Peter, Practical Ethics, 3rd ed. (Cambridge: Cambridge University Press, 2OII).

\section{Political and Legal Philosophy}

Appiah, K. Anthony, and Amy Guttman, Color Conscious: The Political Morality of Race (Princeton, NJ: Princeton University Press, 1996).

Brock, Gillian, Global Justice (Oxford: Oxford University Press, 2009).

Feinberg, Joel, Harm to Others (New York: Oxford University Press, I984).

Kymlicka, Will, Contemporary Political Philosophy, 2nd ed. (Oxford: Oxford University Press, 2002).

Nozick, Robert, Anarchy, State, and Utopia (New York: Basic Books, 1974).

Nussbaum, Martha, Frontiers of Justice: Disability, Nationality, Species Membership (Cambridge, MA: Belknap Press, 2006). 
Rawls, John, A Theory of Justice (Cambridge, MA: Harvard University Press, I97 I).

Sandel, Michael, Justice: What's the Right Thing to Do? (New York: Farrar, Straus and Giroux, 2009).

\section{Topics in Bioethics and Philosophy}

Benatar, David, and David Wasserman, Debating Procreation (New York: Oxford University Press, 2015).

Buchanan, Allen, and Dan Brock, Deciding for Others (New York: Cambridge University Press, I989).

DeGrazia, David, Taking Animals Seriously: Mental Life and Moral Status (New York: Cambridge University Press, I996).

Human Identity and Bioethics (New York: Cambridge University Press, 2005).

Faden, Ruth, and Tom Beauchamp, A History and Theory of Informed Consent (New York: Oxford University Press, 1986).

McMahan, Jeff, The Ethics of Killing (Oxford: Oxford University Press, 2002).

Millum, Joseph, The Moral Foundations of Parenthood (New York: Oxford University Press, 2018).

Norheim, Ole, Ezekiel Emanuel, and Joseph Millum (eds.), Global Health Priority-Setting (New York: Oxford University Press, 2019).

Olson, Eric, The Human Animal: Personal Identity without Psychology (New York: Oxford University Press, I 997).

Schechtman, Marya, Staying Alive: Personal Identity, Practical Concerns, and the Unity of a Life (New York: Oxford University Press, 2014).

Sumner, L. W., Assisted Death (Oxford: Clarendon, 20 I I).

Warren, Mary Anne, Moral Status (Oxford: Oxford University Press, I997).

Wertheimer, Alan, Coercion (Hoboken, NJ: John Wiley \& Sons, I987). 